\title{
Schrankia balneorum (ALPHÉRAKY, 1880) (Lepidoptera, Erebidae) - The first records for Romania
}

\author{
Cosmin O. Manci, Cristian SitaR \& László Rákosy
}

\begin{abstract}
Summary: Three individuals of Schrankia balneorum (ALPHÉRAKy, 1880) are reported for the first time in the Romanian fauna. The three specimens were collected from Stanca village, Iasi country, north-eastern Romania. Photos of the adults as well information about the biology and the distribution of the species are given.
\end{abstract}

Keywords: Schrankia balneorum, Lepidoptera, Erebidae, Romania

\section{Introduction}

The genus Schrankia HüBNER, 1828 covers a huge area in the Northern hemisphere, the Oriental and Australasiatic regions. In Europe 3 species are known Schrankia balneorum (ALPHÉRAKY, 1880), S. taenialis (HÜBNER, [1809]) și S. costaestrigalis (STEPHENS, 1834) (FibigER et al. 2010) and a fourth species S. intermedialis REID, 1972 is considered by Fibigel et al. 2010 as an interspecific hybrid of $S$. costaestrigalis and $S$. taenialis. From Romania two species were known $S$. taenialis și $S$. costaestrigalis, both being relatively rarely recorded from Romania (RÁKosy et al. 2003, RÁKosy 1996). The subspecies S. balneorum bosporella BUDASHKIN \& KLYUCHKO, 1990 was synonymised with the nominotypical ssp. balneorum by FIBIGER et al. 2010.

The occurrence of $S$. balneorum in the SouthEastern parts (Dobrodja region) of the country was suspected, but it had not been proven yet.

\section{Material}

The first two individuals (both males) (Fig. 1) from Romania were collected on 18th of September 2015 from the Stânca village (N47.0698, E27.8038), Iași county, at $50 \mathrm{~m}$ altitude (leg. C. Manci). A third male was collected on 5th of October 2017 from the same locality (leg. C. Manci). The three specimens were lured using a fluorescent $\mathrm{Hg}$ vapour lamp of 160 $\mathrm{W}$ and are deposited in the collection of Cristian Sitar (Cluj-Napoca, Romania).

The habitat in the area corresponds to a traditional low-intensity agricultural mosaic landscape, characterized by the occurrence of steppe-like area (grazed or not) with grassy vegetation or high-salinity areas with specific halophytic vegetation (hight density of Tripolium pannonicum and other salt loving species like undetermined Limonium sp.), shrubs, patches of forests and extensively cultivated patches (Fig. 2).

The area of the village Stanca was already known through some interesting and rare Lepidoptera species in Romania (MANCI et al. 2015, MANCI et al. 2016).

\section{Diagnosis}

The species is relatively similar with $S$. costaestrigalis but is normally much darker and the post medial line in anterior wings is on a different angle (Fig. 3). Worn specimens may need a study of genital structures for a proper identification (FIBIGER et al. 2010).

\section{Biology and ecology}

S. balneorum has a preference for more humid habitats from stepic regions. It was collected in areas with rocky gorges, valleys, small streams and forest edges were the species flies from July to October. This species can be atracted at light or with sugar baits (FiBiger et al. 2010). The early stages and the larval foodplants are little known. According to the latest information, the caterpillar lives on Tripolium pannonicum, T. vulgare and Limonium meyeri (BUdaShKin \& SAVCHUK 2010, SAVCHUK \& KaJgORODOVA 2013). In captivity, the caterpillars accept also Mentha longifolia (BUDASHKIN \& SAVCHUK 2010). Pupation occurs at the end of October and cocoon hangs via a silk line on host plants (BUDASHKIN \& SAvchuK 2010). Several attempts to find the larvae 


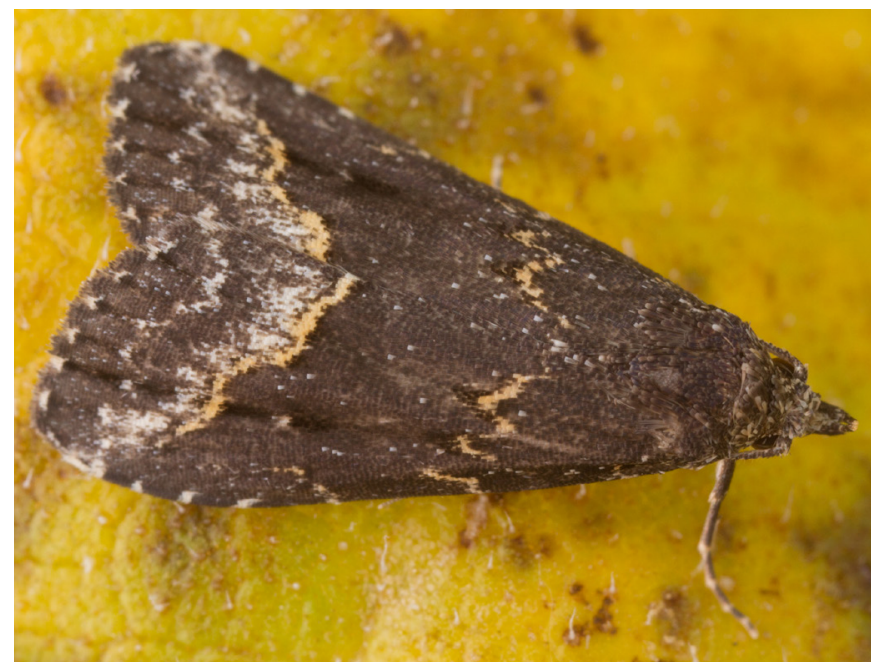

Fig. 1. The first specimen of Schrankia balneorum from Romania collected at Stânca (Iași) on $18^{\text {th }}$ September 2015 (leg. C.O. MANCI). in the Stânca village area have proved unsuccesful, suggesting that the larvae might have more nocturnal habits.

\section{Distribution}

This Ponto-Caspian species is known in Europe from the Crimea and the southern Urals (Fig. 4). There are several other observations from Ukraine and European Russia but these are in need of reconfirmation (FIBIGER et al. 2010). Outside Europe it is known from Turkey, Georgia, Armenia and Azerbaijan (in the Caucasus Mountains where the species was originally described) but also more to the south and east in Region Kopet Dagh between Iran and Turkmenistan and south of Ural Mountains (Alphéraky 1879, Fibiger et al. 2010, PekARsky 2012 and NUPPONEN \& FibigER 2011).

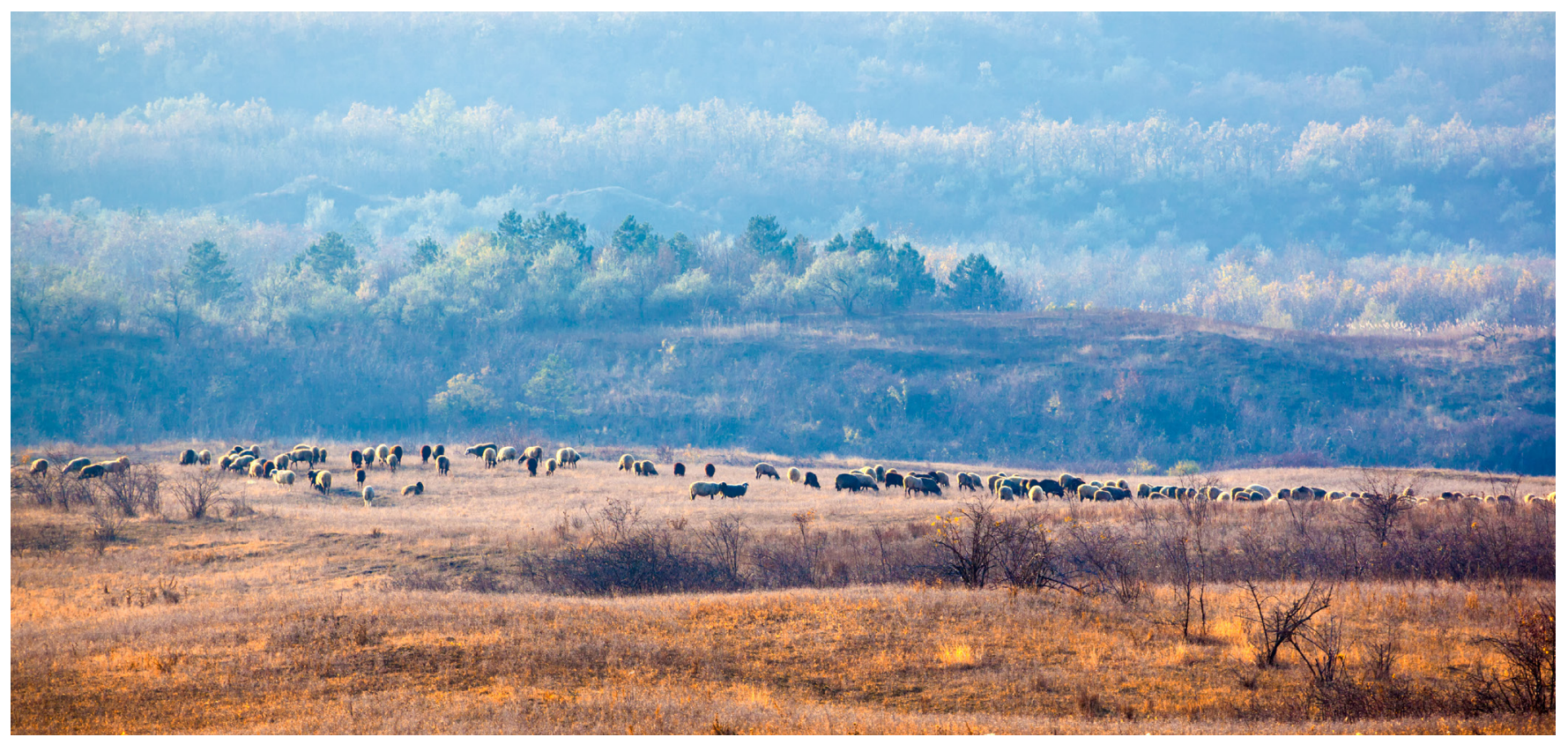

Fig. 2. The habitat of Schrankia balneorum in Stânca (Romania).
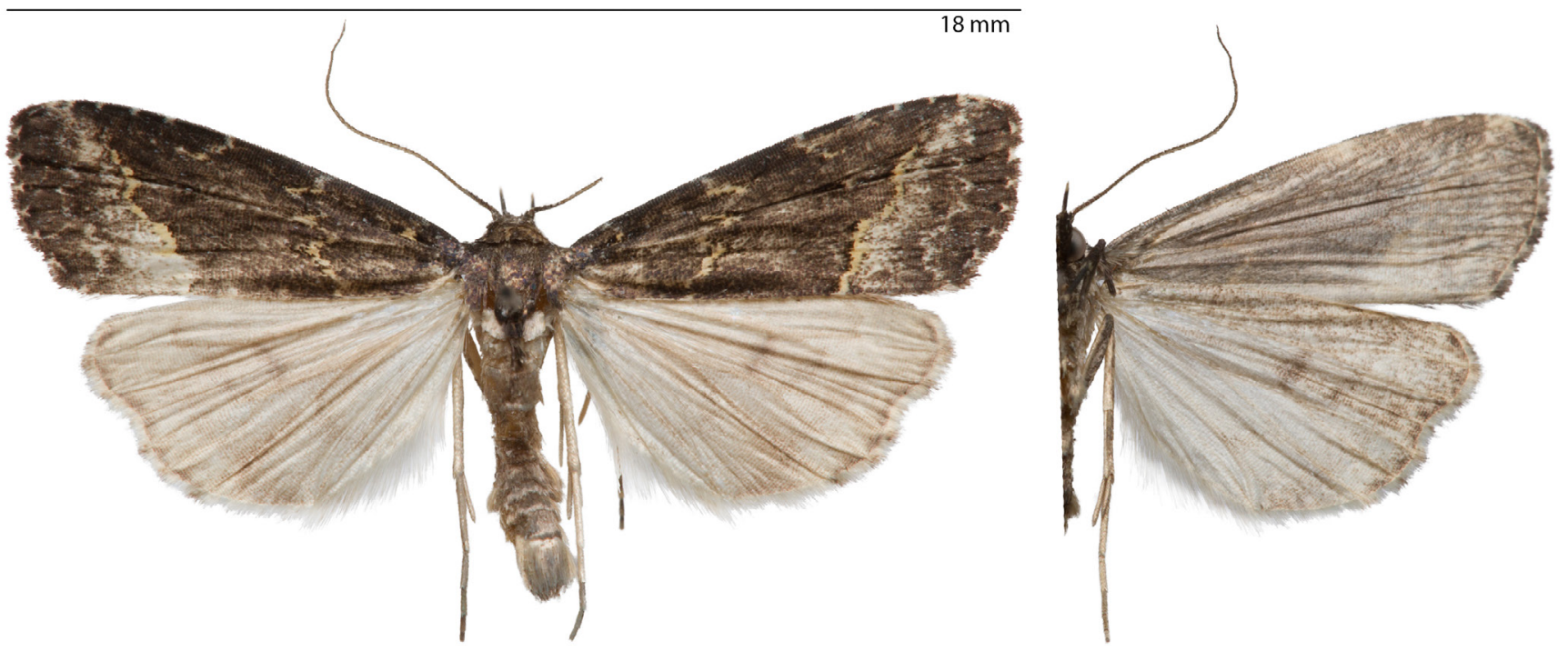

Fig. 3. Schrankia balneorum - dorsal and ventral view of mounted specimen, Stânca (Romania), $18^{\text {th }}$ September 2015 (leg. C.O. MANCI). 


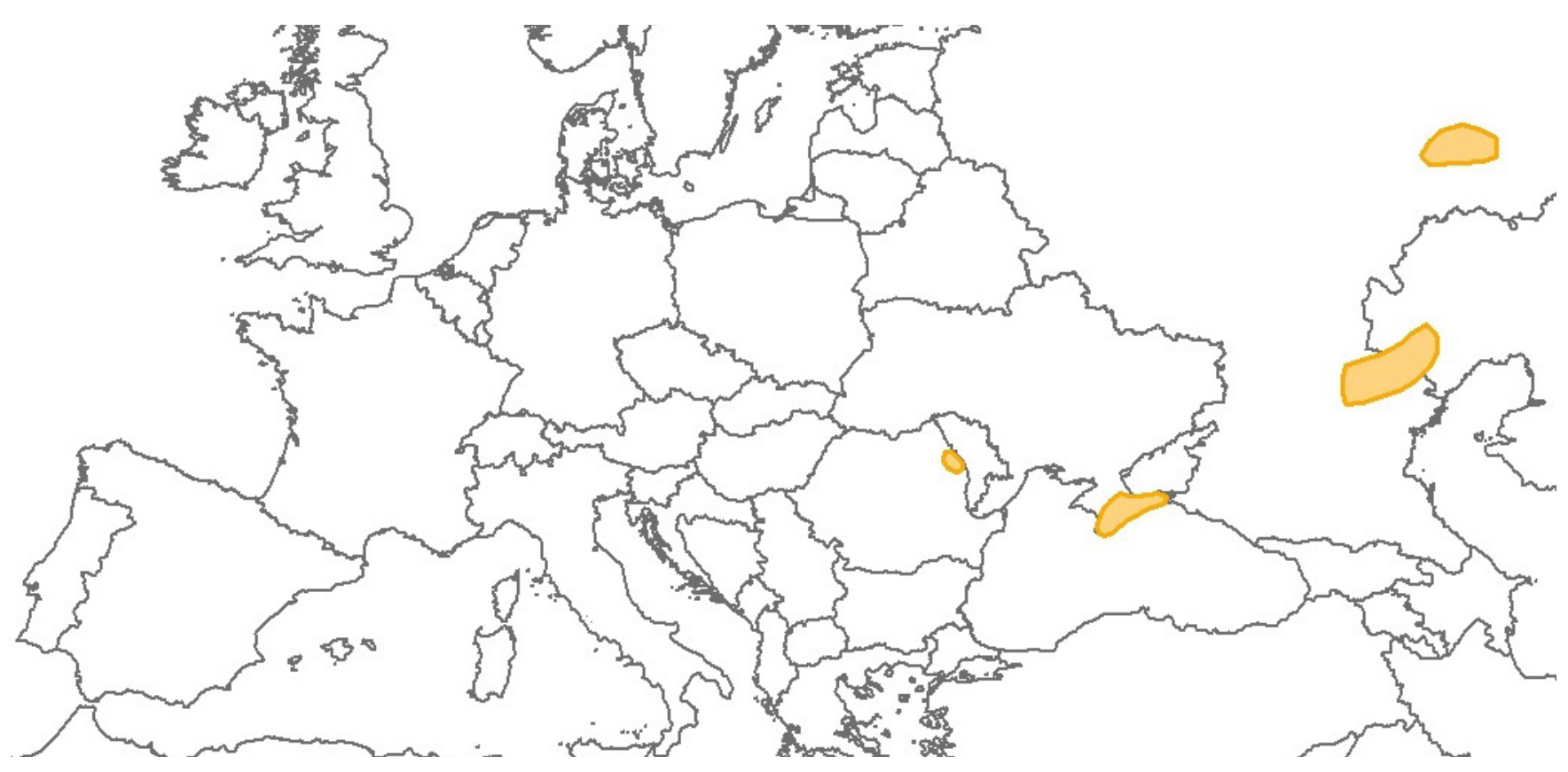

Fig. 4. Distribution map of Schrankia balneorum in Europe (after FIBIGER et al. 2010, modified and supplemented).

\section{Aknowledgements}

We would like to thank Silviu Petrovan for his help with our English manuscrips.

\section{References}

AlphÉRAKy S. (1879) Hypenodes Balneorum, nov. sp. Horae societatis entomologicae rossicae 15: 137-138. St. Pétersbourg

BudashKin Y.I. and SAVChUK V.V. (2010) Additions on the fauna and biology of Lepidoptera of Crimea. Optimization and Protection of Ecosystems 2: $42-57$ (in russian)

Fibiger M., Ronkay L., Yela J. and Zilli A. (2010) Rivulinae, Boletobiinae, Hypenodinae, Araeopteroninae, Eublemminae, Herminiinae, Hypeninae, Euteliinae and Micronoctuidae including Supplement to Volumes 1-11. Noctuidae Europaeae, volume 12. Entomological press, Sorø, 451p.

Manci C.O., Sitar C., Corduneanu C. and Balan C. (2015) First contribution to the study of lepidopteran fauna (Insecta: Lepidoptera) from Stânca, Iași, Moldova region (Romania). Mnemosyne 6: 31-47.
Manci C.O., Sitar C. and Rákosy L. (2016) Lignyoptera fumidaria (Hübner, 1825) (Lepidoptera, Geometridae) -a new FFH Directive protected species in Romanian fauna. Entomologica romanica 19: 17-20.

Nupponen K. and Fibiger M. (2011) Additions to the checklist of Bombycoidea and Noctuoidea of the VolgoUral region. Part II. (Lepidoptera: Lasiocampidae, Erebidae, Nolidae, Noctuidae). Nota Lepidopterologica 35(1): 33-50.

PEKARSKY O. (2012) A new species of Schrankia Hübner, 1825 from China (Lepidoptera, Erebidae, Hypenodinae). ZooKeys 242(242): 43-50. doi:10.3897/ zookeys.242.3856. PMC 3561679. PMID 23378796.

Rákosy L., GoiA M. and Kovacs Z. (2003) Catalogul Lepidopterelor României. Soc. Lepid. Rom., Cluj Napoca 446p.

RÁKosy L. (1996) Die Noctuiden Rumaniens. Staphia, Linz, 648p.

SavchuK V.V. and Kajgorodova N.S. (2013) New information on the fauna and biology of the owlet moths (Lepidoptera: Noctuidae s. 1.) from Crimea. Optimization and Protection of Ecosystems 9: 13-30 (in russian).
Cosmin-Ovidiu MANCI

Oceanographic Research and Marine Environment Protection Society Oceanic-Club, Decebal 41

Constanta, Romania

E-mail: cosminom@gmail.com
Cristian SITAR

Zoological Museum

Babeș-Bolyai University, Clinicilor 5-7

Cluj-Napoca, Romania

E-mail: cristiansitar@yahoo.com
László RÁKosy

Department of Taxonomy and Ecology Babeș-Bolyai University, Clinicilor 5-7 Cluj-Napoca, Romania

E-mail: laszlorakosy@ubbcluj.ro

Received: 31.10 .2018

Accepted: 30.11.2018

Published online: 31.12 .2018

Published: 31.12.2018

Online article number: ER22201804

doi: 10.24193/entomolrom.22.4 